\title{
'Containerization in Globalization': A Case Study of How Maersk Line Became a Transnational Company
}

\author{
Henrik Sornn-Friese
}

\section{Introduction $^{1}$}

Studies on the role of containerization in globalization have centred either broadly on the history of the liner shipping industry, ${ }^{2}$ or more narrowly on strategic alliances ${ }^{3}$ and global maritime networks. ${ }^{4}$ Most of these studies in addition have been carried out at the industry level and have

\footnotetext{
${ }^{1}$ This chapter is generally based on and extends an earlier article, written in Danish, Sornn-Friese (2017).

${ }^{2}$ Broeze (2002), Donovan and Bonney (2006), Levinson (2006), Slack and Frémont (2009), and van Ham and Rijsenbrij (2012).

${ }^{3}$ Rimmer (1998), Ryoo and Thanapoulou (1999), Broeze (2002), and Slack et al. (2002).

${ }^{4}$ Frémont (2007, 2010), Gadhia et al. (2011), Ducruet and Notteboom (2012), and Ducruet (2016).
}

\footnotetext{
H. Sornn-Friese $(\bowtie)$

Department of Strategy and Innovation, Copenhagen Business School, Frederiksberg, Denmark

e-mail: Hs.si@cbs.dk
} 
largely neglected the strategic dynamics associated with identifying business opportunities at home and abroad, the mobilization of resources, and efforts to continually adjust company strategy and organization. This chapter adds to the literature in two ways. Firstly, by shifting the unit of analysis from that of industry to that of the firm and, secondly, by focusing on the process of a company's transnationalization, which entails the establishment of a global network of subsidiaries orchestrated by a central corporate headquarters. ${ }^{5}$

The chapter uses a historical case study of Maersk Line, the world's leading container carrier. Maersk Line's global leadership was achieved within a relatively short time period and was the result of Mærsk McKinney Møllers decision in 1973 to enter container shipping - the biggest investment in the history of the AP Moller companies. Maersk Line has since grown into the world's largest container ship operator with almost 33,000 employees in 130 countries, a fleet of 639 container ships serving 59,000 customers around the globe, more than 300 own company offices in 121 countries, global service centres in Denmark, the Philippines, India and China, and access to 343 port terminals and inland transport facilities in 61 countries, partly through its sister company APM terminals.

Why did Maersk Line decide to become a global company, and how did it manage so quickly to achieve leadership in an industry dominated by a small number of consortia organized in cartel-like liner conferences? The major features in the company's development are well documented, but the story of how Maersk Line became a transnational corporation is an overlooked chapter. ${ }^{6}$ The replacement of long-established third-party agency agreements with own offices after 1974 was a decision of great importance that enabled superior services globally. The motto 'service all the way' was the hallmark and a major driving force for the company. In a rare interview, the person in charge of the new container initiative, $\mathrm{Mr}$ Ib Kruse, explained how the company's competitiveness rested on a service 'second to none', realized through the combination of modern and effective company-owned ships with sophisticated equipment developed

\footnotetext{
${ }^{5}$ Bartlett (1986).

${ }^{6}$ Hornby (1988) and Jephson and Morgen (2014).
} 
in-house, a global network of own company offices and high-level communication, and sophisticated documentation and control systems. ${ }^{7}$ This chapter examines the development of these elements.

Through interviews with current and former employees of the AP Moller-Maersk Group, documents from the company's private archives and various secondary sources, the transnationalization of Maersk Line is studied as an 'extended era', limited in time and focusing on the substitution of third-party agents abroad with own country offices. With inspiration from the theory of dynamic capabilities the chapter seeks to explain how Maersk Line created an efficient global organization while adapting its services to local market needs in the countries where it operates. ${ }^{8}$ The chapter demonstrates strategic change by examining the company's ability to capture and understand new business opportunities, seize them and change the company's core competencies. The study of such dynamic capabilities provides new perspectives for the understanding of transnational corporations. ${ }^{9}$

The analysis focuses largely on the period from 1974 to 1999 , during which the establishment of the company's global network of own overseas offices was particularly pronounced. In this period, the company's many country managers had, as 'entrepreneurs and kings', the responsibility to create profits in their own country, and there were many local investments in container shipping and related services. ${ }^{10}$ The Copenhagen headquarters decided on the overall strategy for Maersk Line and had a direct role in local development, but country offices were run as profit centres. Towards the end of the period, culminating in the acquisition of Safmarine and SeaLand in 1999, the organization changed gradually, with the multifarious activities increasingly organized into independent product lines.

\footnotetext{
${ }^{7}$ Ikeda (1980).

${ }^{8}$ Teece et al. (1997) and Eisenhardt and Martin (2000).

${ }^{9}$ Teece (2014).

${ }^{10}$ Jensen (2014).
} 


\section{A Transnational Company}

Unlike the global companies of the eighteenth and nineteenth centuries, primarily plantation, mining and international trade, which were typically state-supported monopolies on specific trades within the European colonies, modern transnational companies such as Maersk Line are characterized by their involvement in direct business activities abroad and their ability to profit from cooperation and international division of labour. ${ }^{11}$

The decision in 1973 to enter into container shipping was the start of Maersk Line's deep internationalization, developing as a genuine transnational corporation. Not only is Maersk Line today a huge and diverse company that serves customers around the globe with different needs and expectations, its activities are also managed so as to provide economies of scale through a global organization while the company can concurrently handle various conditions in different regions of the world and differentiate its services to local needs.

Several factors differentiate the transnational company from other international companies. ${ }^{12}$ Transnational companies are able to plan, organize, coordinate and control their business activities across countries - typically from a central headquarters and through the setting of common goals and strategies. Characteristically, they promote multiple internal management perspectives, through which they can decode and respond to the diversity of external demands and opportunities; their interdependent physical assets and management capabilities are distributed internationally; and they have a strong unifying management approach. ${ }^{13}$ The latter is characterized by top management's ability to synchronously manage context, processes and content. Context management is the task of providing a structure for delegated decision-making based on clear goals and priorities, career development for leaders with a global mindset, and established decision-making procedures. Top management's direct intervention in organizational processes may include minor modifications, typically handled through continuous monitoring and additional decision

\footnotetext{
${ }^{11}$ Hymer (1971) and Heaver (2010).

${ }^{12}$ Bartlett and Ghoshal (1989).

${ }^{13}$ Bartlett (1986).
} 
support, as well as major interventions (such as establishing temporary working groups and task forces) in larger or more complex situations. Through content management, top management intervenes directly in local decision-making situations, if an issue remains unresolved, or if a previously selected solution proves unsatisfactory.

Soon after World War II Maersk Line had established a handful of offices abroad, and these became important for the subsequent container endeavour and for the building of the company's transnational organization from the middle of the 1970s. The latter followed the expansion of the trade network, where new regions were gradually added. In each region, Maersk Line established key country offices, while in individual ports and certain mainland hubs it opened up small branch offices. In the few locations that did not offer enough business volume to form a true profit centre, the company continued to be represented by third party agents.

Only Taiwan's Evergreen matched Maersk Line's approach in scope and dedication, and the two became the first real transnational companies in international container shipping. Although there was strategic awareness of the importance of strong representation locally, Maersk Line's global organization was not the result of a conscious transnational strategy, but rather of a long process of change in which the company reacted to business opportunities as they arose and dismissed the elements it found not to work. It is true, however, that container shipping, at least initially, required proximity to the customers, that certain economies of scale to some extent justified strong local country offices, and that the strength of the company's distinct entrepreneurial culture, where it 'was better to get forgiveness than to get permission', made it desirable to have a functioning internal sharing of knowledge and information. ${ }^{14}$ All this contributed to the transnationalization of Maersk Line through a period when container shipping-driven by the transition from general cargo traffic to standard containers and the relocation of production from the West to low-wage countries in Southeast Asia-was a high-growth market.

${ }^{14}$ Jensen (2014). 


\section{The Establishment of the First Maersk Line Offices Abroad}

Shortly after World War I Arnold Peter Møller started tramp shipping services in the US freight market, from where he soon also served the Far East. In 1919 he and his cousin, Hans Isbrandtsen, who had immigrated to the United States in 1915, together founded the Isbrandtsen-Moller Company (ISMOLCO) in New York. The international activities of the AP Moller-companies thus early on included ownership and strategic management control across borders. In 1928 ISMOLCO went into the liner business of shipping cargo from the US East Coast via the Panama Canal to the Far East, and hence Maersk Line was born. The Panama line was successful, and in 1931 Maersk Line had three ships in regular services on the route.

Like most liner companies Maersk Line employed local agents in the ports where the company's ships were calling. ISMOLCO was an agent for Maersk Line in the United States, and a few years after the establishment of the Panama line Mr Møller had built a network of third-party agents in Asia. The network comprised of the shipping departments of large industrial companies, such as Mitsubishi of Japan and Compañía General de Tabacos de Filipinas ('Tabacalera') in the Philippines, ${ }^{15}$ and international trading houses specialized in liner shipping, such as, Melchers \& Co in Shanghai (1931-1946), Jebsen \& Co in Hong Kong (1946-1975) and in Shanghai (1946-1969), and Tait \& Co in Taiwan. ${ }^{16}$ The latter were typically larger companies each with their portfolio of agencies and with their own teams dedicated to each customer. During 1973-1976 Chris Jephson was employed by Tait \& Co in Taiwan and responsible for their Maersk Line team, a group of 15-16 people focused exclusively on servicing Maersk Line. Tait \& Co was agent for more than 70 shipping

\footnotetext{
15 During his visit to Manila in 1930, Mr Møller had urged Tabacalera, one of the largest sugar producers in the Philippines, to establish its own shipping department, which subsequently became Maersk Line's General Agent in the country. Please see, Hornby (1988).

${ }^{16}$ Tait \& Co was a subsidiary of the British-owned Harrisons \& Crosfield Ltd, an international trading company that would later serve as agents for Maersk Line in several districts of India and, from 1953 to the outbreak of the Civil War in 1958, in Indonesia.
} 
companies from around the world, several of which were Maersk Line's direct competitors. ${ }^{17}$

WWII put a temporary halt to Maersk Lines' activities, but from 1946 the Panama line was reopened. In the post-war years, Maersk Line established country offices in Thailand, Indonesia, the United States and Japan. The four offices proved important for the development of Maersk Line's global organization after 1974. Moreover, in 1951 Maersk Company Limited was established in London as an independent company that could operate the AP Moller fleet under the British flag in the event of a new war in Europe. Similarly, during the Cold War, Maersk Inc. in New York (see below) developed as a separate shadow headquarters that could take over the Maersk Line fleet in the event of a new war in Europe.

The first country office had been established in New York, where Mærsk Mc-Kinney Møller stayed during WWII. Along with Thorkil Høst, the former head of the AP Moller liner department in Copenhagen, he founded the Interseas Shipping Company. The new company, which in 1943 changed its name to Moller Steamship Company, was set to replace ISMOLCO as agent for Maersk Line in the United States, as A. P. Møller had decided to break with his cousin. When Mærsk Mc-Kinney Møller in 1947 moved back to Denmark, the Moller Steamship Company was fully staffed and operational and busy rebuilding the Panama line. Under Høst's leadership from 1947 to 1967, the Moller Steamship Company grew into a large and successful company with autonomous top management and Board of Directors. In 1955 the company established its own office in Los Angeles and in 1973 extended with an office in San Francisco. After the containerization of Maersk Line the company quickly built an extensive network of own offices in the United States and Canada.

From early spring 1946 the ships were once again fully loaded travelling from the United States to the Far East, and many of the customers from before the war returned to Maersk Line. ${ }^{18}$ It was, however, difficult to generate backhaul from the Far East to the United States, and Maersk Line was working keenly to adapt its agent network in Asia to generate homegoing cargoes. Cooperation with the agents in Hong Kong, Manila and

\footnotetext{
${ }^{17}$ Personal interview with Chris Jephson, 11 November, 2016.

${ }^{18}$ Hornby (1988).
} 
Taiwan were strengthened, but to access the lucrative Japan traffic, which in the post-war years was reserved for American tonnage, the company had to make a detour. ${ }^{19}$ In 1947, Mærsk Mc-Kinney Møller therefore established Maersk Line Ltd (MLL) in Delaware, which gave access to the Asian countries managed by the Americans under General Douglas MacArthur, the Supreme Commander of the Allied Powers. In 1948, MLL opened up its own country office in Yokohama south of Tokyo and branch offices in Kobe and Osaka, and in 1958 it expanded with a branch office in Jakarta, replacing the existing agency agreement with Harrisons $\&$ Crosfield in Indonesia. MLL was mainly an administrative unit and it played no direct commercial role for Maersk Line until 1983 when it got a contract with the US Defense Department.

The branches in Japan and Indonesia developed in a short time to become important country offices for Maersk Line in the Far East, and Japan became a bridgehead to Thailand. In September 1949, the first Maersk Line ship called on Bangkok with the supply of railway equipment from Japan to the Thai State Railways. The new Japan-Thailand route, which in the following year was extended to the Persian Gulf, provided safe and regular cargo, and already in 1951 Maersk Line established an office in Bangkok, which soon was as important as the country offices in Japan and Indonesia.

Maersk Line expanded dramatically during the post-war period with the establishment of new routes. In addition to Japan-Thailand and JapanPersian Gulf, it established a transatlantic line in 1947 (which was closed down again in 1954), a Suez line in 1949, a Japan-Indonesia line in 1952, a Gulf of Mexico-West Africa line in 1958 and a Japan-West Africa line in 1959 .

Table 5.1 shows Maersk Line's coverage through third-party agents and own offices in 1958. With continuous network expansion, the company's agent network grew significantly in the post-war years, and there was an increased need for coordination and information exchange. From 1956 there would be regular meetings between the Principal Agents and the liner department in Copenhagen. The first Principal Agents' Meeting was held North of Copenhagen and lasted two days, and the meetings were then

${ }^{19}$ Hornby (1988). 


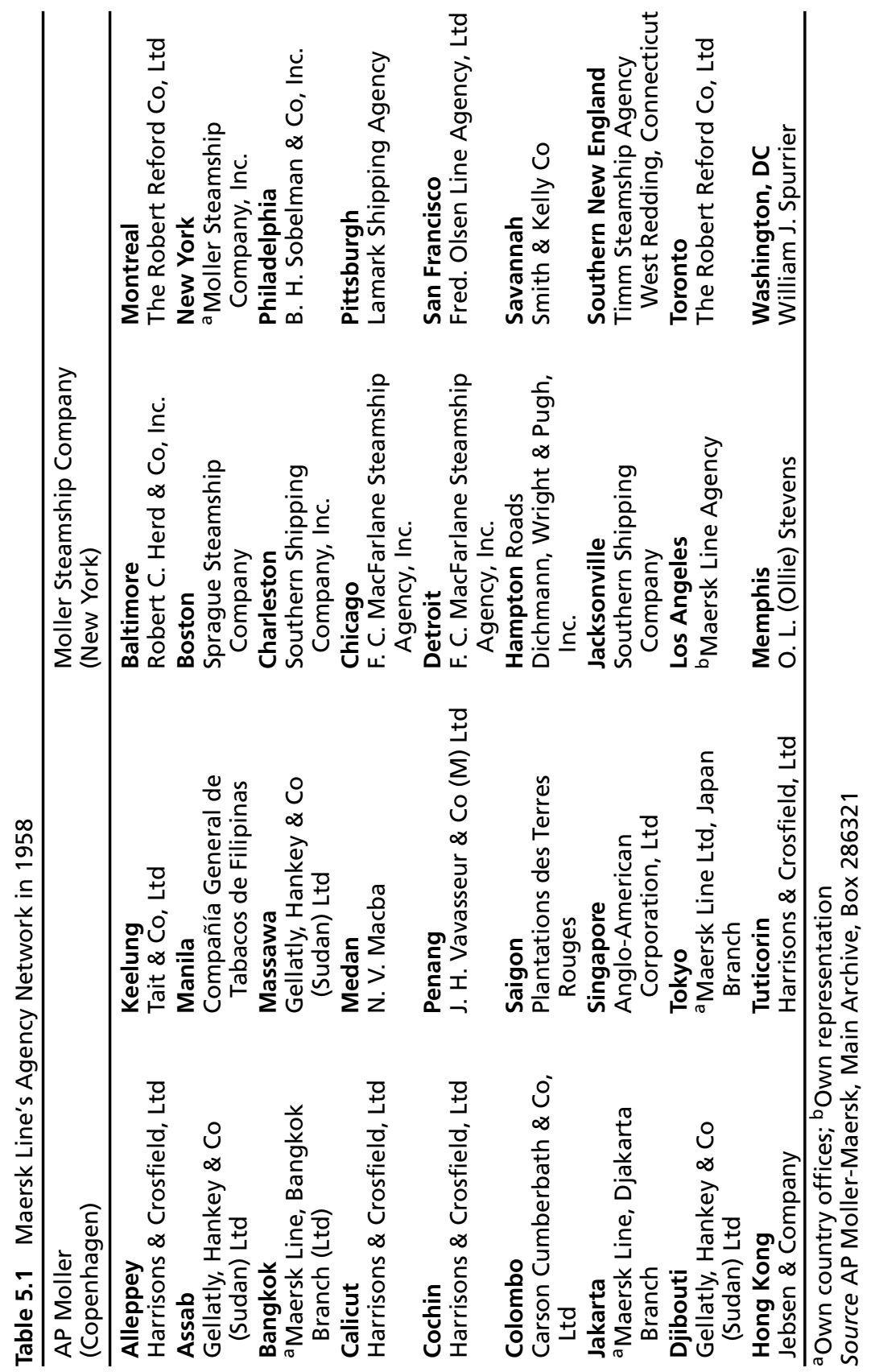


repeated at 2-3 year intervals. ${ }^{20}$ When Maersk Line almost two decades later went into container shipping, the agent meetings had become weeklong events with executives from Copenhagen and the principal agents from around the world. Although they were indeed autonomous and legally independent companies, the principal agents were considered an integral part of Maersk Line, as made apparent by A. P. Møller in his welcoming speech during the second Principal Agents' Meeting in 1958: 'You are now all in the Maersk family, and we are happy to have you as members thereof. You have all done a good job to serve as a member of that family, and I hope that you will all continue to make the Maersk name honoured, respected, and still growing. I thank you, Gentlemen!'. ${ }^{21}$

\section{Developments 1974-1999}

Maersk Line's international organization proved to be an important prerequisite for the company's success in container shipping. The country managers in the United States, Japan, Thailand and Indonesia (so-called 'Maersk Top') were part of the 'crash committee' established by Mærsk Mc-Kinney Møller in early 1970 with the task to investigate whether the Panama line should be containerized. ${ }^{22}$ Prior to this there had been a cautious attempt to initiate a containerized service between Asia and Europe in cooperation with Japanese ' $\mathrm{K}$ ' Line, but the Japanese had terminated the partnership and Maersk Line's first container ship had instead been chartered out. The four-country managers were deeply involved in the decision to containerize the line and their country offices were important building blocks in the unfolding of this new venture globally. ${ }^{23}$ Local presence along the Panama line was crucial for success as the ultimate goal was a worldwide door-to-door service in which the company would control the customer's transport task from supplier to final destination. ${ }^{24}$ The

\footnotetext{
${ }^{20}$ Hornby (1988).

${ }^{21}$ AP Moller-Maersk, Main Archive, Box 161332.

${ }^{22}$ Jephson and Morgen (2014).

${ }^{23}$ Pedersen and Sornn-Friese (2015).

${ }^{24}$ Jephson and Morgen (2014).
} 
country managers contributed international knowledge and experience as well as an organizational platform for the containerization of the line.

'Maersk Container Line' was initially shielded from AP Moller's conventional liner business and was a small unit in Copenhagen with only five employees: Ib Kruse (managing director), Flemming Jacobs (marketing and sales), Niels Jørgen Iversen (ship operations), Birger Riisager (finance and IT) and Erik Holtegaard (conference matters). Globally the unit had only about 30 employees. The recommendations from the crash committee to the organization were: 'Develop the essential management organization, taking account of both the new skills that will be necessary and the quality of staff required in each location'. ${ }^{25}$ In 1974 it was decided to establish country offices in Hong Kong and Singapore, and from that time onwards there was rapid establishment of offices in Asia, Europe and North America and later in the rest of the world, as illustrated in Fig. 5.1.

The establishment of country offices were each international episodes of great importance and can be described as revolutionary steps towards the transnationalization of Maersk Line, whereas the creation of smaller, local offices were gradual extensions in an ongoing, evolutionary internationalization process. ${ }^{26}$ Each country office was established as a profit centre-an independent, and in the country legally domiciled, company with its own board and management. Each establishment had thus a long-term perspective; they were 'good citizens' locally and not temporary structures aimed at 'looting. ${ }^{27}$ Country managers were typically expat Danes sent from the Copenhagen headquarters, while the other employees in the offices were well-qualified locals recruited from the shipping and freight forwarding industry. The focus on own country offices was on building a global agency network, with emphasis on the word 'network': although the offices were established as profit centres, there was a strong central management from Copenhagen in the form of advanced IT systems and behavioural incentives, and effective socialization mechanisms worked to interconnect the organization across countries and companies.

\footnotetext{
${ }^{25}$ AP Moller-Maersk, Main Archive, Box 151747.

${ }^{26}$ For the distinction between evolutionary and revolutionary internationalization processes, please see Kutschker et al. (1997).

${ }_{27}$ Personal interview with Flemming Jacobs, 10 March, 2017.
} 


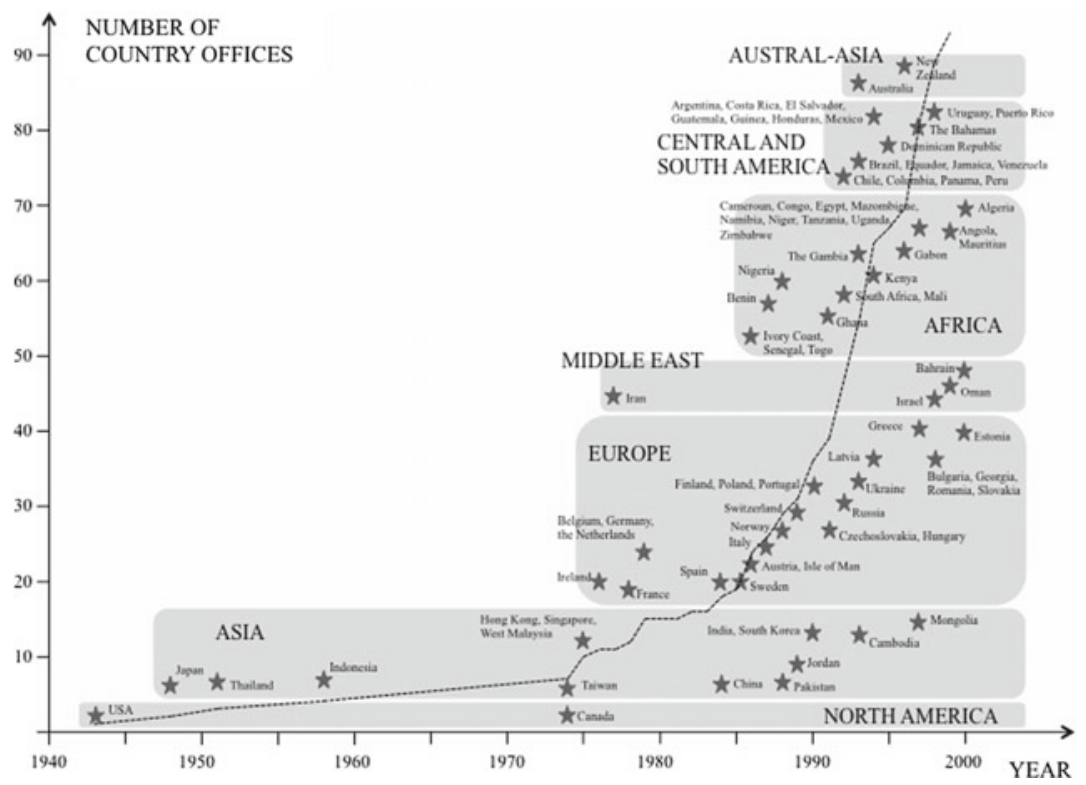

Fig. 5.1 The establishment of Maersk Line country offices (Source AP MollerMaersk, Main Archive, various boxes)

- Employees were carefully selected and tested. Already in the 1960 s McKinney-Møller had introduced a so-called Predictive Index (PI) system for staff assessment, where employees were measured on intellect and personality. From this system was drawn a global inventory of talents that could be called upon whenever the organization lacked 'the right person at the right time and place'.

- Employees were stationed in a country for a number of years and then either sent on to another country for an additional time period or back to the head office in Copenhagen. In that way, employees developed actual country experience and international perspective, and they forged strong ties to other Maersk people, essentially forming a 'Maersk-blue brotherhood'.

- Marketing and Sales was a primary management philosophy. A comprehensive and detailed marketing manual had been developed for use in the conventional liner business in 1974, the distribution of which 
was restricted to Maersk Line personnel and agencies. The manual specified the Maersk Line logo, which consisted of two elements: 'a Maersk blue square with rounded corners containing a white seven-pointed star ("standing on two points"), and the name Maersk Line'. ${ }^{28}$ It also specified in great detail how the logo should be applied in communication (e.g., transportation documents, cover letters, envelopes, name badges, and business cards), on the company's ships and vehicles, and in other advertisement (match boxes, playing cards, pencils and pens, memo pads, calculators, alarm clocks, LEGO ship models, and more). All overseas offices would use the manual to ensure that sales and marketing was handled properly.

- Similarly, there was a written manual for the design of Maersk Line offices, narrowly specifying the choice of colours, furniture and office wall art (the offices should always have pictures of A. P. Møller and Mærsk Mc-Kinney Møller as well as the Danish Royal family). The manual also promoted a strict dress code, however allowing for smaller deviations to accommodate to local customs in the different countries.

- There was outspoken focus on training and education, particularly in sales. The company's global sales training program was managed from Copenhagen, but performed and adapted locally. With the rapidly expanding global organization the company's training efforts were vigorously developed, and from 1993 firmly established in the M.I.S.E. program ('Maersk International Shipping Education'), which annually attracted more than 85,000 applicants worldwide to around 500 trainees positions. ${ }^{29}$

In 1967, Poul Rasmussen replaced Thorkil Høst as country manager in the United States, and after the decision to containerize the Panama line in 1973 he replaced the company's third-party agents in the United States with own offices in the most important ports. These typically focused on sales and customer services, but in major ports such as Baltimore and Charleston they would also carry out ship operations. In 1978, Alfred B. ('Ted') Ruhly took over after Rasmussen. Among many other initiatives,

\footnotetext{
${ }^{28}$ Maersk Line Communication Manual, Issued 1 August 1974.

${ }^{29}$ Sornn-Friese et al. (2012).
} 
Ruhly introduced quality circles in the organization, based on the principle that 'what gets measured, gets done'. Quality Control subsequently spread to Maersk Line globally as a key underpinning in being 'second to none'.

When Moller Steamship Company in 1988 changed its name to Maersk Inc. and moved to larger premises in New Jersey, it had more than 30 own offices in the United States and Canada. The name change was a result of increased marketing of the Maersk brand, but the company's function was unchanged. Maersk Inc. had a high degree of autonomy from Copenhagen, partly due to the business volume based on the remarkable Post-WWII expansion of the US economy and the importance of the Panama service to Maersk Line, and partly due to the role the organization got with Mc-Kinney Møller's residence in the United States during WWII. In the 1990s, the culture to some extent was a reflection of the culture in Copenhagen but mixed with strong elements of American leadership. ${ }^{30}$ When Maersk Line acquired Sea-Land in 1999 Maersk Inc. played a major role, both in the dialogue with the US authorities and in the work to get the two companies integrated. With the acquisition of Sea-Land, Maersk Inc. more than doubled in size and was now by far the largest shipping company in the Americas with more than 100 offices in the United States, Canada, South America, Central America, and the Caribbean. ${ }^{31}$

Until the mid-1990s the establishment of new country offices followed in a steady stream and anchored Maersk Line in Eastern Europe as well as in Africa, China and the Middle East. In the locations where Maersk Line, due to local institutional conditions, could not be established with whollyowned subsidiaries, the company would set up exclusive Maersk Line units in the organizations of its third-party agents. Having own employees stationed was considered as a key issue, partly with the aim to inject the right dose of 'Maersk blue blood' in the organization and partly to provide own people with specific country experiences and an international outlook.

In 1993, Maersk Line went into nine new countries and 24 overseas Maersk Line offices were added to the organization. Particularly interesting

\footnotetext{
${ }^{30}$ Benson and Lambek (2000) and Jensen (2014).

${ }^{31}$ Nissen (2000).
} 
was the establishment in Australia and the continuation of containerization of routes within Asia. These included the acquisition of EAC's Far East Line and certain of their offices in the area. This all happened before the intra-Asia container market became the world's largest. Included in the acquisition of EAC's Far East Line was an Eastern Australian service between Melbourne, Sydney, Brisbane and two ports in Japan and Korea, as well as a Western Australian service between Fremantle, Singapore, Malaysia, Hong Kong and Taiwan. The EAC's intra-Asia services were also included in the deal and were continued from Singapore through Maersk Line's new subsidiary MCC Transport.

\section{Containerization of the Europe/Asia Route}

In the late 1970s it was decided to containerize the important Suez line running between Europe and Asia. The Suez line had originally been established in 1946, when the company experimentally let the ships that had sailed out on the Panama line return to the United States via South and Southeast Asia and the Red Sea. ${ }^{32}$ With the decision to start a weekly independent container service between Asia and Europe ten new large container ships were ordered, and the organization in Western Europe was considerably strengthened. Long-held agency agreements were replaced with own country offices: Dublin in 1976, Paris in 1978 and Hamburg, Rotterdam and Antwerp in 1979. In addition, the company established its own local branch offices in Bremen, Düsseldorf, Nürnberg, Stuttgart, Frankfurt, Munich and Amsterdam. The European focus was gradually extended first to Scandinavia in 1985 with an owned office, Maersk Line (Sverige) AB, in Gothenburg and smaller, local branch offices in Stockholm and Helsingborg and then to Eastern Europe. With the continued expansion of Maersk Line in Europe new agency agreements were made with third-party providers in new countries, only to be replaced with own Maersk Line offices later on. In Helsinki, for example, an agreement was entered with OY Jacobsen Shipping Ltd in 1976 and replaced with an owned office in 1990. This stepping-stone approach was a means for

${ }^{32}$ Hornby (1988). 
Maersk Line to build up country experience in new markets that would later be used as lever for an own establishment.

Various documents related to the company's Europe Project show that Belgium, The Netherlands and Germany formed the core of containerization of the Suez line. ${ }^{33}$ Experienced Maersk employees were installed as Board of Directors and together with the newly appointed country managers were directly involved in hiring high-calibre senior people to lead the main functions of the three offices. The offices were also linked to the company's new electronic systems that Maersk Data had developed in collaboration with Cable \& Wireless in London for container management and documentation on the Panama line.

On Saturday, 28 June 1980, the country managers and senior people from the Europe offices together with the third-party agents in Switzerland, Denmark, Norway and Sweden were invited to a full-day information session in Copenhagen. Senior managers from Copenhagen and top officials from the advertising company Young \& Rubicam also joined the meeting. On the program were the key elements in Maersk Line's management philosophy: ships and operations, marketing and sales, financial management and the unique IT systems. Sales philosophy was a significant strategic directive for the company: Maersk Line should offer a superior service and be known as the prime alternative to the three large container consortia Trio, Scan Dutch and ACE Group, which controlled more than $90 \%$ of container shipping on Asia-Europe through the cartellike Far Eastern Freight Conference (FEFC). Maersk Line's partnership with Young \& Rubicam was important and close. It was an integral part of getting the new container concept rolled out and marketed. Young \& Rubicam had its own team of employees living and breathing for Maersk Line.

33 AP Moller-Maersk, Main Archive, Box 151957 and Box 151963. 


\section{The World's Most Profitable Container Shipping Line}

In 1985, it was decided that Maersk Line should become 'the most profitable international container transportation company in the world' ${ }^{34}$ This objective was to be achieved through first-class services, global coverage, and door-to-door services-three elements that from the beginning were captured in the motto 'service all the way'. To achieve the objective required outstanding ships and equipment, well-trained and highly motivated employees, maximum cost-effectiveness, tailor-made customer services, and investments in specialized tonnage and equipment for niche markets. With the objective followed a genuine growth strategy to be pursued through a combination of increased transport frequency in existing markets and entry into new geographic markets. The growth would be based on the experiences with the containerization of the Panama line, and should preferably be organic.

The establishment of own offices in key locations were formalized in the company's new growth strategy: 'Maersk Line must have as an objective to be represented by their own agencies, where this is feasible'. The strategy included detailed plans for the establishment of new offices in Europe, Asia and Africa, and for each country a short comment was attached. ${ }^{35}$ For Italy it was noted, for example, that the previously used agent was 'owned and managed by aging Italians with no apparent dynamic crown princes'. For West Africa the note was more comprehensive: 'The ongoing study by the Line Department is expected to lead to a positive conclusion on the establishment of own companies in Ivory Coast, Togo and maybe Senegal to achieve overall control and undertake direct sales, customer service, documentation and container control-possibly leaving vessels' operations sub-contracted to existing agencies'.

In 1986, the remaining conventional liner services were merged with the container business in Maersk Line as a separate business unit and expanded with a new container line between Europe, the Middle East and West Africa. It was also somewhat of a stroke of genius to build a private

${ }^{34}$ AP Moller Maersk, Archive of Mr Ib Kruse, Box 122118.

${ }^{35}$ AP Moller Maersk, Archive of Mr Ib Kruse, Box 122118. 
container terminal in what had hitherto been a fishing port in Algeciras in southern Spain. The project was simply called CPS - to keep it secret, which Maersk Line had the habit of, also regarding the current capacity of its container vessels. ${ }^{36}$ CPS stood for 'Connecting Point Spain'. The basic idea of the concept included serving main lines by large container vessels avoiding 'convoy sailings', serving feeder legs by a flexible fleet easily adjustable in time with even short-term market fluctuations, and the availability of efficient berthing and operation facilities at the connecting point. ${ }^{37}$ This involved replacing the 10-12 general cargo vessels on the existing conventional route from Asia to West Africa with only four major feeder ships of the line between Algeciras and West African ports. This hit two birds with one stone: first, utilizing capacity on ships from Asia to North Europe by stopping in Algeciras, and second, delivering the goods in West Africa much faster than had been the case on the longer way with general cargo vessels, and thus provide even better customer service. It would also save Maersk Line huge shipping costs.

\section{A Deeper Reflection: The Establishment in Southeast Asia in 1975}

Press releases brought in a number of Hong Kong, Singapore and Malaysian newspapers in the second half of 1974 showed that Maersk Line, with effect from 1 January 1975, would end the longstanding collaborations with third-party agents in Hong Kong and Singapore and set up its own offices. ${ }^{38}$ As reasons were stated the company's new and large exposures in the container era. Strategically the decision was founded in the desire to establish Maersk Line as a strong brand and provide 'service all the way', but the timing was prompted by inadequate services from the existing agents. Maersk Line had already opened an own office in Taipei the year before. Even at the commencement of containerization in

\footnotetext{
36 Personal interview with Flemming Jacobs, 10 March, 2017.

${ }^{37}$ AP Moller-Maersk, Main Archive, Box 285835.

${ }^{38}$ AP Moller-Maersk, Line Management Archive, Box 220732 and Box 220730.
} 
1975 Taiwan was a very important market for Maersk Line, so a smoothly functioning and tightly controlled local operation was deemed crucial.

With the containerization of the Panama line the company decided to relinquish its 'serving Japan first' approach and instead focus on Southeast Asia, and there were careful considerations behind this choice. ${ }^{39}$ Importers in Southeast Asia had begun to avoid lines that passed via Japan, and while Japan's imports from the United States were expected to considerably increase at the time, such increase would be in value rather than in tonnage. Moreover, Japan was the area in the Far East with the toughest liner competition and consequent over-tonnage. Tariff rates between the United States and Japan on general cargo were also lower than to Southeast Asia, and rebating more prevalent.

Even more important, however, was the decision to continue serving the markets that Maersk Line had built up long before the container eramainly niche exports from the United States to Southeast Asia, where especially Hong Kong, Singapore and Taiwan were important destinations. ${ }^{40}$ A major customer was Caterpillar, one of the world's leading manufacturers of construction machinery, but Maersk Line also carried frozen food, fresh fruit and much more. Not only did the dedication to existing customers imply that Maersk Line had to be strongly represented locally in Southeast Asia, but also that the bet on containerization required investments in flexible vessels and equipment. For example, with specially-built 'artificial tween-decks', which were portable 'three container cells wide' platforms that could be inserted into the stow of mainline container vessels as well as feeder vessels at any depth and in any hold, ${ }^{41}$ Maersk Line could continue transporting heavy loads of non-standard size and shape. The tween-decks enabled heavy loads to be handled by shore container cranes without interrupting the flow of units. Containers were furthermore developed for niche requirements. With the transport of fresh fruit and frozen chicken it was important that the temperature in the containers could be adjusted as needed, and hence Maersk Line developed the refrigerated container with the cooling unit located on the container.

\footnotetext{
${ }^{39}$ AP Moller-Maersk, Main Archive, Box 151747.

${ }^{40}$ Personal interview with Flemming Jacobs, 10 March, 2017.

${ }^{41}$ Grey (1975).
} 
During that period, the major ports in Southeast Asia were gradually switching to container shipping. ${ }^{42}$ In 1966 the authorities in Hong Kong and Singapore had independently appointed committees to assess the implications of containerization and make recommendations on the establishment of container terminals, and in 1967 Malaysia had also initiated a major investigation. Through private investments, Hong Kong had opened its first container terminals between 1970 and 1973, and Singapore, which had achieved independence from first the United Kingdom in 1963 and subsequently from Malaysia in 1965, had also moved quickly to maintain its importance as a regional hub and inaugurated its first container terminal in 1972. ${ }^{43}$ Finally, in 1973 the container activities had developed in Malaysia's main port, Port Klang. The changing requirements of containerization were formidable and eventually would completely transform the ports in Southeast Asia. In the middle of the 1990s a walk around the Hong Kong container terminals was a 'walk around a ghost town populated only by tall machines' as containerization had 'moved the traditional godown and warehouse away from its historic home at the edge of the sea' and moved depots and freight stations to 'the hinterland away from dock thieves, salt water, and sometimes maritime expertise'. 44

Maersk Line's competitors provided shuttles between Northeast Asia and the United States, but Maersk Line's focus on existing customers led to a different business model. Rather than concentrate traffic to the Pacific mainline the company chose to continue to serve destinations, which at that time did not even have container facilities in their ports nor a well-functioning inland transport infrastructure. In some of the places the transport conditions on land were very simple and land transportation was by truck only. This meant that Maersk Line's containerization objectives required the development of extensive areas for storing containers and suitable transport infrastructure in the countries, another good reason for being strongly established with own offices locally.

\footnotetext{
42Trace (1997).

${ }^{43}$ Levinson (2006).

${ }^{44}$ Ignarski (1995, 95).
} 
For the containerization of its Panama line the company therefore chose a weekly service from the United States directly and deeply into Southeast Asia and then returning to the United States via Japan, as evident from Maersk Line's Master Plan shown in Table 5.2. At a speed of 25 knots per

Table 5.2 The Master Plan for the containerization of the Panama line

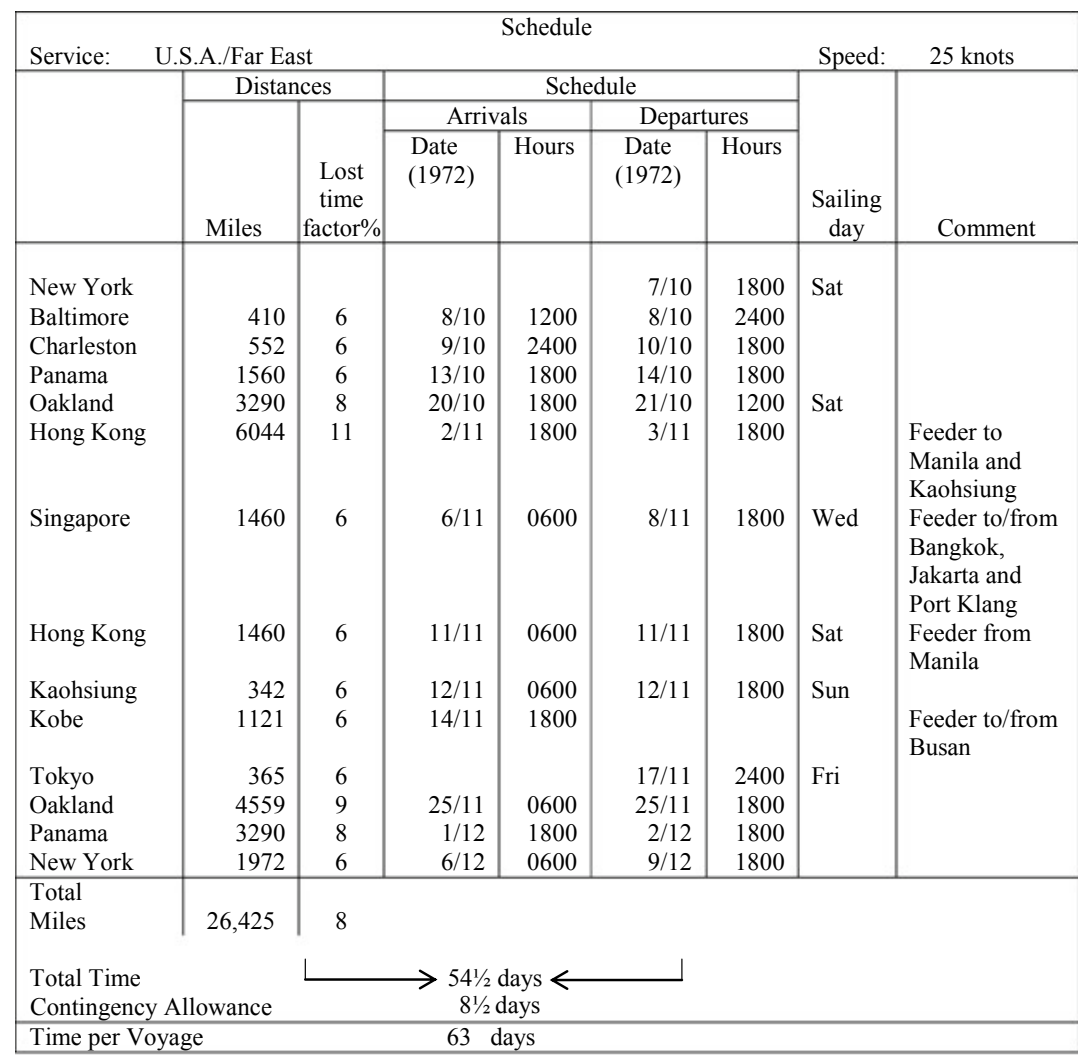

\begin{tabular}{lr} 
Steaming & 44 days \\
Sea margin $(8 \%)$ & $3 \frac{1}{2}$ days \\
Cargo handling time & $81 / 2$ days \\
Canal passing & 2 days \\
Contingency allowance & 5 days \\
Total round voyage & 63 days \\
\cline { 2 - 2 }
\end{tabular}

Source AP Moller-Maersk, Main Archive, Box 151747 
hour a reliable weekly service could be maintained with the company's nine newly built 1200 TEU mainline vessels in the A-series (the vessels were given names starting with the letter A), which was crucial for the new business model. As a novelty in international container shipping at the time, Maersk Line established a fixed schedule with port calls at certain weekdays. None of Maersk Line's competitors were geared for such an operation. ${ }^{45}$ The new advertising slogan 'You can set your watch by Maersk' served to visualize the business model. ${ }^{46}$

\section{Execution}

The venture into containerization was essentially different from conventional liner shipping, and especially Maersk Line's business model put great demands on service and customer experience. It was vital to provide consistent service to all shippers and receivers anywhere on the planet, and the company could not build a successful business if it had to rely on the various routines and systems of its many third-party agents. A strong local presence in the Southeast Asian countries was therefore considered crucial to the new business model.

Minor adjustments were made to the containerization master plan. The Master Plan had stipulated a direct service to Kaohsiung in the south of Taiwan to commence in 1975. The Port of Kaohsiung had expanded greatly in the period after WWII culminating in 1975 with the completion of 'the Second Harbour', built to accommodate modern container vessels. During the following decades, the Port of Kaohsiung would develop into a regional hub port, or 'load centre' on a par with Hong Kong and Singapore. ${ }^{47}$ The Master Plan however was implemented with the big ships calling from Hong Kong directly to Keelung in the north of Taiwan and then onwards to Japan, and at least initially Maersk Line would instead serve Kaohsiung by feeder. In the mid-1970s, nearly all the high-value exports from Taiwan were concentrated in the north of Taiwan, in the area around Taipei,

\footnotetext{
45 Pedersen and Sornn-Friese (2015).

${ }^{46}$ Jephson and Morgen (2014).

47Trace (1997).
} 
with some along a corridor towards Taichung in the centre West Coast of Taiwan, the latter of which was also the area for high-value imports (e.g., machinery, weaving equipment). Because the transport infrastructure on land was quite primitive at the time, Maersk Line decided to maintain its longstanding focus on the much closer Keelung, and while the main competitors, particularly Sea-Land and American President Lines, did call Kaohsiung directly, this decision gave Maersk Line a 1-2 days competitive advantage on top of its fast transit to the United States' West Coast. ${ }^{48}$ Only years later did Maersk Line's big ships call directly at Kaohsiung.

Frictions in the relationship with the existing agents also provided an occasion to move fast in Hong Kong, Singapore and Malaysia. Maersk Line's principal agent for Hong Kong and Macao through 43 years was Jebsen \& Company, a respected Danish-owned company domiciled in Hong Kong. In Jebsen's shipping department 25 employees worked exclusively for Maersk Line, and they had always provided a quality service for Maersk Line's conventional liner traffic. In the early 1970s, the Head of the AP Moller liner department in Copenhagen, Christian Lund, however, noted challenges with Jebsen \& Company and after having vainly tried to place one of his own people at Jebsen's offices Maersk Line decided to terminate the agency agreement and instead establish its own office. ${ }^{49}$

In Singapore and West Malaysia there was also an experience of inadequate service from the Anglo-American Corporation, Maersk Line's principal agent for the two countries since 1953, and again it was decided to terminate the agreement and establish own offices. In a letter to Ib Kruse the recently appointed owner-representative of Maersk Line in the area, Niels Lillelund Jørgensen, claimed 'the urgent need of a solution', and to Christian Lund he stressed the need to establish a strong own organization in the area: 'with the start of the new container line Singapore will become so important that it will be necessary to have a strong organization. (...) An own office will also be able to develop business opportunities in Maersk

\footnotetext{
${ }^{48}$ Personal e-mail correspondence with Chris Jephson, 7-9 August 2017.

${ }^{49}$ AP Moller-Maersk, Line Management Archive, Box 220732.
} 
Supply Service, Maersk Air, Sales \& Purchasing, Chartering and Brokerage, Financial operations (incl. Asian Dollar), Industry, Maersk Drilling (incl. Aquadril), and so on'. ${ }^{50}$

After the decision was made to establish own offices in Hong Kong and Singapore the company moved fast with the registration of the new companies, obtaining work and residence permits, staffing, preparation of internal manuals and furnishing office space. The latter was considered important for cultivating employees and maintaining a strong corporate culture. ${ }^{51}$ Country managers were appointed among experienced Maersk people who would hit the ground running, while senior staff and other employees were recruited locally, most of them directly from Jebsen and Anglo-American, respectively. Half a year later, Maersk Line also established its own organization in Malaysia with a large office in Port Klang and small offices in Kuala Lumpur and Penang, with 'Danish supervision as needed from Singapore'. 52

The new offices were given the important task to organize port facilities throughout Southeast Asia and to secure Maersk Line vessels reliable access to the terminals. They were also involved in the roll-out of new advanced IT systems developed by Maersk Data. It was particularly important to get a handle on documentation so that customers at any time could track their cargo, and so that the conclusion of tasks could proceed smoothly. The new A-series of container vessels sailed so fast that it was not possible for the necessary documents to keep up with the normal way of transfer, but with the new IT systems the necessary information could quickly be transmitted from one end of the world to the other and printed locally. This was something that greatly differentiated Maersk Line from its competitors in Southeast Asia. Finally, the two offices were heavily involved in launching the company's first global sales training programme with the aim to professionalize the sales function in Maersk Line and ensure that the company could deliver consistent service globally.

\footnotetext{
${ }^{50}$ AP Moller-Maersk, Line Management Archive, Box 220730.

${ }^{51}$ Jensen (2014).

52AP Moller-Maersk, Line Management Archive, Box 220730.
} 
The new country offices were hugely important for subsequent developments. They were crucial for the ability to detect and respond to unexpected changes in the market, and they established Maersk Line as an important name in Asia and founded the network to the major shippers and other important players. Local presence enabled not only superior and consistent service and the establishment of the necessary infrastructure and complementary assets locally, but also a good feel for the market and its development. It was thus Maersk Line offices locally in Asia and North America, which put the company in a position soon to perceive and quickly respond to the significant growth and development of the Asian economies, which really took off with 'exports in the opposite direction' in the late 1970s and helped making the Panama line profitable. ${ }^{53}$

The offices' local status and the strong network later proved crucial for getting access to Vietnam, the Bay of Bengal and China, among others. In 1984 the Hong Kong office established its first representation in Guangzhou in Mainland China, and from here the number of Maersk employees in the People's Republic of China over ten years increased to more than 100 people across 12 offices. Since the Chinese authorities would only allow foreign companies to operate in China via local agents, the offices were in the beginning run in joint venture with Chinese interests, but in 1994 Maersk Line was the first foreign shipping company authorized to establish a private, wholly-owned company with business activities everywhere in China. With this development the number of Maersk Line employees in China quadrupled in just one year. ${ }^{54}$

\section{Conclusion}

Maersk Line has always been an international company, but with the transition to container shipping in the early 1970s the company chose to focus globally in the sense that its many work processes were spread to locations across the globe, often with a high degree of autonomy locally but integrated in a way that accommodated Maersk Line's overall goals. The

\footnotetext{
53 Jephson and Morgen (2014).

${ }^{54}$ Simonsen (1994).
} 
goal was to deliver a worldwide, door-to-door container transport based on superior and consistent service. This chapter has shown how Maersk Line approached the task, including how the company established a global organization with strong local representation.

The internationalization of Maersk Line was a learning process in which the company reacted to business opportunities as they arose. Although there was a desire to have local representation in profitable markets, the transnationalization of the company can best be described as emergent rather than following a strategic plan. The initiative to own overseas offices, which were established as independent companies with their own management and board of directors, as a rule came from the head office in Copenhagen, but the further strategic development for individual countries were then left largely to the 'Maersk Top' in each country. The process was guided by some more or less well-defined management tools including explicit 'fundamental company objectives', a logic of operational independence, value-based decision heuristics, a focus on the importance of 'Maersk-blue blood' that resulted in a special 'man on the ground' philosophy, and customized training programs overseen by the Copenhagen headquarter; as well as special global information and communication systems developed specifically for Maersk Line.

When considering how Maersk Line managed to achieve global leadership in a period of just about 25 years, the chapter has pointed to the importance of the company's own country offices that allowed the interconnection of three types of networks: The physical network of ships and routes, the digital network of information and communication systems, and the human network of Maersk employees. The interaction between the vessels, the systems and the people is still at the core of the company today and central to its continued development.

\section{References}

Bartlett, C. A. (1986). Building and Managing the Transnational: The New Organizational Challenge. In M. E. Porter (Ed.), Competition in Global Industries (pp. 367-401). Boston: Harvard Business School Press. 
Bartlett, C. A., \& Ghoshal, S. (1989). Managing Across Borders: the Transnational Solution. Boston: Harvard Business School Press.

Benson, P. S., \& Lambek, B. (2000, August 23). United Maersk of America. Politiken. Section 3, 1; Jensen, Culture Shock in Maersk Line.

Broeze, F. (2002). The Globalisation of the Oceans: Containerisation from the 1950s to the Present. St. John's: IMEHA.

Donovan, A., \& Bonney, J. (2006). The Box That Changed the World: Fifty Years of Container Shipping - An Illustrated History. East Windsor: Commonwealth Business Media.

Ducruet, C. (2016). Maritime Networks: Spatial Structures and Time Dynamics. Milton Park: Routledge.

Ducruet, C., \& Notteboom, T. (2012). The Worldwide Maritime Network of Container Shipping: Spatial Structure and Regional Dynamics. Global Networks, 12(3), 395-423.

Eisenhardt, K. M., \& Martin, J. A. (2000). Dynamic Capabilities: What Are They? Strategic Management Journal, 21(10/11), 1105-1121.

Frémont, A. (2007). 'Global Maritime Networks: The Case of Maersk. Journal of Transport Geography, 15(6), 431-442.

Frémont, A. (2010). Maritime Networks: A Source of Competitiveness for Shipping Lines. In K. Cullinane (Ed.), International Handbook of Maritime Business. Cheltenham: Edward Elgar.

Gadhia, H. K., Kotzab, H., \& Prockl, G. (2011). Levels of Internationalization in the Container Shipping Industry: An Assessment of the Port Networks of the Large Container Shipping Companies. Journal of Transport Geography, 19(6), 1431-1442.

Grey, M. (1975, October 2). Maersk Begins Its Trans-Pacific Container Challenge. Fairplay International Shipping Weekly, pp. 7-9.

Heaver, T. D. (2010). The Dynamic Role of International Shipping in Business Structures and Relationships. In E. van de Voorde \& T. Vanelslander (Eds.), Applied Transport Economics: A Management and Policy Perspective. Antwerp: Antwerpen De Boeck.

Hornby, O. (1988). 'With Constant Care... '. A.P. Møller: Shipowner 1876-1965. Copenhagen: J. H. Schultz.

Hymer, S. H. (1971). The Multinational Corporation and the Law of Uneven Development. In J. N. Bhagwati (Ed.), Economics and World Order (pp. 113-140). London: Macmillan.

Ignarski, S. (1995). The Box: An Anthology Celebrating 25 Years of Containerisation and the TT Club. London: TT Club. 
Ikeda, M. (1980, October 29). Maersk's Containerization Plan in F.E./Europe Trade Explained. Shipping and Trade News.

Jensen, L. (2014). Culture Shock in Maersk Line: From Entrepreneurs and Kings to Modern Efficiency. Copenhagen: Vespucci Maritime Publishing.

Jephson, C., \& Morgen, H. (2014). Creating Global Opportunities: Maersk Line in Containerisation 1973-2013. Cambridge: Cambridge University Press.

Kutschker, M., Bäurle, I., \& Schmid, S. (1997). International Evolution, International Episodes, and International Epochs-Implications for Managing Internationalization. Management International Review, 37(2), 101-124.

Levinson, M. (2006). The Box: How the Shipping Container made the World Smaller and the World Economy Bigger. Princeton and Oxford: Princeton University Press.

Nissen, A. (2000, December 6). Mærsk Inc.: Trimmet til vækst. Jyllands-Posten. Section 4, 8.

Pedersen, T., \& Sornn-Friese, H. (2015). A Business Model Innovation by an Incumbent Late Mover: Containerization in Maersk Line. In N. J. Foss \& T. Saebi (Eds.), Business Model Innovation: The Organizational Dimension (pp. 217-239). Oxford: Oxford University Press.

Rimmer, P. J. (1998). Ocean Liner Shipping Services: Corporate Restructuring and Port Selection/Competition. Asia Pacific Viewpoint, 39(2), 193-208.

Ryoo, D. K., \& Thanapoulou, H. A. (1999). Liner Alliances in the Globalization Era: A Strategic Tool for Asian Container Carriers. Maritime Policy and Management, 26(4), 349-367.

Simonsen, J. D. (1994, May 17). Mærsk udvider kraftigt i hele Kina. Berlingske Tidende. Section 3, 5.

Slack, B., Comtois, C., \& McCalla, R. J. (2002). Strategic Alliances in the Container Shipping Industry: A Global Perspective. Maritime Policy and Management, 29(1), 65-76.

Slack, B. J., \& Frémont, A. (2009). Fifty Years of Organizational Change in Container Shipping: Regional Shift and the Role of Family Firms. GeoJournal, $74(1), 23-34$.

Sornn-Friese, H. (2017). Transnationaliseringen af Maersk Line: fra tredjepartsagenter til egne kontorer i udlandet. Økonomi \& Politik, 90(2), 46-58.

Sornn-Friese, H., Poulsen, R. T., \& Iversen, M. J. (2012). “Knowing the Ropes”: Capability Reconfiguration and Restructuring of the Danish Shipping Industry. In S. Tenold, E. Lange, \& M. J. Iversen (Eds.), Global Shipping in Small Nations: Nordic Experiences After 1960. London: Macmillan. 
Teece, D. J. (2014). A Dynamic Capabilities-Based Entrepreneurial Theory of the Multinational Enterprise. Journal of International Business Studies, 45(1), $8-37$.

Teece, D. J., Pisano, G., \& Shuen, A. (1997). Dynamic Capabilities and Strategic Management. Strategic Management Journal, 18(7), 509-533.

Trace, K. (1997). ASEAN Ports Since 1945: Maritime Change and Port Rivalry. In F. Broeze (Ed.), Gateways of Asia: Port Cities of Asia in the 13th-20th Centuries (pp. 318-338). London: Kegan Paul.

van Ham, H., \& Rijsenbrij, J. (2012). Development of Containerization: Success Through Vision, Drive and Technology. Amsterdam: IOS Press.

Open Access This chapter is licensed under the terms of the Creative Commons Attribution-NonCommercial-NoDerivatives 4.0 International License (http:// creativecommons.org/licenses/by-nc-nd/4.0/), which permits any noncommercial use, sharing, distribution and reproduction in any medium or format, as long as you give appropriate credit to the original author(s) and the source, provide a link to the Creative Commons license and indicate if you modified the licensed material. You do not have permission under this license to share adapted material derived from this chapter or parts of it.

The images or other third party material in this chapter are included in the chapter's Creative Commons license, unless indicated otherwise in a credit line to the material. If material is not included in the chapter's Creative Commons license and your intended use is not permitted by statutory regulation or exceeds the permitted use, you will need to obtain permission directly from the copyright holder. 